\title{
EFFECT OF PHYTASE SUPPLEMENTATION ON GROWING PIGS PERFORMANCE
}

\author{
ŠEFER D*, PETRUJKIĆ B*, MARKOVIĆ RADMILA*, GRDOVIĆ SVETLANA*, NESTOROVIĆ B**, \\ BOGOSAVLJEVIĆ $\mathrm{V}^{\star *}$, KOKOŠKOV $\mathrm{N}^{\star * *}$ and MILIĆ $\mathrm{D}^{\star \star * \star *}$ \\ *University of Belgrade, Faculty of Veterinary Medicine, Belgrade, Serbia \\ ${ }^{* *}$ Clinical Centre of Serbia, Clinic for neurosurgery, Belgrade, Serbia \\ ***General Secretariat of the President of the Republic of Serbia, Belgrade, Serbia \\ $\star \star \star \star$ Perutnina Ptuj Topiko,Bačka Topola, Serbia
}

(Received 5th Aprol 2012)

Dietary concentrations of phytate are crucial for its anti-nutritive properties and its negative impact on $P$ availability. The increase of dietary phytate level is shown to increase endogenous losses of amino acids and minerals in pigs. The partial availability of the $P$ component of phytate to simple-stomached species attains importance as the world's rock phosphate reserves are not renewable, which could lead to a $P$ supply crisis in the future. Supplementing phytase is becoming increasingly common as a method to improve the availability of $P$ in plant ingredients containing high levels of phytate $P$.

Fourty-eight pigs (Swedish Landrace boars $\times$ Dutch landrace sows) weaned at day 35 with an initial BW of $8.72 \pm 0.28 \mathrm{~kg}$ were used for a 40-day weaner performance study. The study was structured as a complete randomized design to evaluate the response of weaner pigs to four concentrations of microbial phytase produced by Aspergillus niger: (T1) basal diet; (T2) basal diet + 1000 FTU/kg; (T3) diet with decreased dicalcium phosphate + 1000 FTU/kg; and (T4) diet with no dicalcium phosphate + 1000 FTU $/ \mathrm{kg}$.

Control group of piglets (T1) has achieved standard body mass while addition of phytase in meal increased body mass by $6.59 \%$ in T2 and $7.52 \%$ in T3. Phytase supplementation prevented decreased body weight gain diets where available phosphorous level was reduced by 50. The amount of consumed feed per day was not significantly different. Feed efficiency of T2 and T3 groups was by $3.23 \%$ better and of T4 for $11.29 \%$ lower compared to the control group of piglets (T1).

Lower production results achieved by the use of low phosphorous diets can be avoided to a certain level by the use of microbial phytase. The use of phytase in pig diet significantly improved phosphorous availability, as well as of other mineral substances from the phytate complex.

Key words: growth performance, phytase, pigs, supplementation 


\section{INTRODUCTION}

Phosphorous, necessary for skeleton formation and growth, is involved in the metabolism of lipids, carbohydrates and fats. It is a constitutive element of energy rich molecules (adenosine triphosphate and creatine phosphate), nucleic acids and of blood and rumen buffers. In cases of low phosphorous deficiency the first clinical symptom is decreased appetite followed by lower availability of nutrient matters, decreased body mass and production results. Longer deficiency leads to inadequate bone mineralization which results in soft fragile bones in young (rachitis) and old animals (osteomalacia) (Šefer and Sinovec, 2008).

Phytate was first identified more than a century ago (Hartig, 1855). Phytate and phytate-bound phosphorus $(\mathrm{P})$ is present in all diets and the partial availability of phytate-P has long been recognized (Lowe et al., 1939). The partial availability of the $\mathrm{P}$ component $\left(282 \mathrm{~g} \mathrm{~kg}^{-1}\right)$ of phytate to simple-stomached species assumes importance as the world's rock phosphate reserves are not renewable, which could lead to a P supply crisis in the future (Mullaney et al., 2000). Environmental regulations have set strict limits on the level of $P$ to be discharged in swine effluents (Vats et al., 2005; Selle and Ravindran, 2008). In addition, the inclusion of excessive levels of inorganic $P$ results in higher feed costs. The global harvest of crop seeds and fruits contains an estimated 14.4 million tonnes of phytate-P, which is equivalent to $65 \%$ of annual sales of $\mathrm{P}$ as fertilizers (Lott et al., 2000). Logically, dietary concentrations of phytate are crucial to its anti-nutritive properties and its negative impact on $\mathrm{P}$ availability. The addition of sodium phytate to glucose-based diets has been shown to increase endogenous losses of amino acids and minerals (Cowieson et al., 2004). It follows that responses to phytase will be more pronounced with increasing dietary phytate levels and indications of this have been recorded in poultry (Ravindran et al., 2006) and pigs (Selle et al., 2003). Because available $P$ reserves are finite, even higher costs are expected in the future (Cordell et al., 2009). Hence, there is a need to develop nutritional strategies which use the concept of $P$ bioavailability, thus, we can provide adequate $P$ to satisfy the animal's needs.

Supplementing phytase is becoming increasingly common as a method to improve the availability of $P$ in plant ingredients containing high levels of phytate $P$ (Selle and Ravindran, 2008). Phytase feed enzymes have a more general application as their substrate is invariably present in pig and poultry diets and their dietary inclusion economically generates bioavailable $\mathrm{P}$ and reduces the $\mathrm{P}$ load on the environment.

Animal nutritionists have long regarded phytate as both indigestible and an anti-nutritional factor for non-ruminant animals (Swick and Ivey, 1992). Phytate is ubiquitous in plant-sourced feed ingredients as it serves as a $\mathrm{P}$ reservoir during seed germination.

The inclusion of feed enzymes in poultry diets to enhance nutrient utilization and performance by counteracting the negative influence of targeted substrates has become common place within the last two decades (Selle and Ravidran, 2007). 
Although phytase activity was first detected in rice bran more than a century ago (Suzuki et al., 1907), attempts to develop a phytase feed enzyme did not commence until 1962 in North America (Wodzinski and Ullah, 1996). Nevertheless, it was not until 1991 that the first phytase feed enzyme became commercially available, which was largely in response to the legislation designed to limit P pollution of the environment in the Netherlands. Phytase, which occurs widely throughout nature, is the enzyme needed to degrade phytate and it has the capacity to hydrolyze phytate and release inorganic P (Selle and Ravidran, 2007).

Several distinct microbial phytase products are now commercially available. The three commonly used phytase feed enzymes are derived from $A$. niger, which is a 3-phytase (EC 3.1.3.8) and Peniophora lycii and Escherichia coli, which are 6phytases (EC 3.1.3.26). Phytase feed enzymes may be included in poultry rations as granulates or as liquids, via post-pelleting application systems, to avoid thermostability problems at high pelleting temperatures $\left(>80^{\circ} \mathrm{C}\right)$. There are, however, perceived advantages in inherently heat stable phytase feed enzymes that can withstand steam-pelleting, as illustrated by the investigations of Wyss et al. (1998) and Garrett et al. (2004).

In the $A$. niger phytase introduced in 1991, phytase activity is defined as fytase units (FTU), where one FTU is the amount of enzyme that liberates $1 / \mathrm{mol}$ inorganic orthophosphate/min from $0.0051 \mathrm{~mol} \mathrm{~L}^{-1}$ sodium phytate at $\mathrm{pH} 5.5$ and at a temperature of $37^{\circ} \mathrm{C}$ (Engelen et al., 1994).

The hypothesis of this study was that inclusion of phytase (1000 phytase units $(\mathrm{FTU}) / \mathrm{kg}$ ) in a low-P weaned pig diets will affect available $\mathrm{P}(\mathrm{aP})$ and prevent reduced growth performance when fed low- $P$ weaned pig diets.

\section{MATERIAL AND METHODS}

Animals and procedures. Fourty-eight pigs (Swedish Landrace boars $\times$ Dutch landrace sows) weaned at day 35 with an initial BW of $8.72 \pm 0.28 \mathrm{~kg}$ were used for a 40-day weaner performance study. The pigs were penned (1.68x $1.22 \mathrm{~m}$ ) in a house with fully slatted floors, and each pen contained one male and one female, resulting in 12 replicates per treatment. Feed and water via nipple drinkers were available ad libitum. Room temperature was set at $26^{\circ} \mathrm{C}$ for the first week and was reduced by $2^{\circ} \mathrm{C}$ per week to $22^{\circ} \mathrm{C}$. Animals were weighed on days 0,20 and 40. Feed samples were collected each day and retained for chemical analysis at $-20^{\circ} \mathrm{C}$. Samples of freshly voided feces were collected on days 0,20 and 40 and frozen $\left(-20^{\circ} \mathrm{C}\right)$ for laboratory analysis (determination of available $\mathrm{P}$ (aP) content).

Experimental design and diets. The study was designed as a complete randomized design to evaluate the response of weaner pigs to four concentrations of phytase: (T1) basal diet; (T2) basal diet + $1000 \mathrm{FTU} / \mathrm{kg}$; (T3) diet with decreased dicalcium phosphate + $1000 \mathrm{FTU} / \mathrm{kg}$; and (T4) diet with no dicalcium phosphate $+1000 \mathrm{FTU} / \mathrm{kg}$. The microbial phytase used was produced by Aspergillus niger (Natuphos ${ }^{\circledR}$ BASF Corporation, Ludwigshafen, Germany).

Phytase was initially mixed with approximately $10 \mathrm{~kg}$ of ground wheat prior to being added to the mixer to ensure homogeneity. Each diet was manufactured 
in an $800 \mathrm{~kg}$ batch. All diets were formulated to have identical concentrations of $\mathrm{Ca}$, digestible energy and ileal digestible lysine (INRA-AFZ, 2004). All other amino acid requirements were provided relative to lysine according to the ideal protein concept (NRC, 1998). All diets were fed as meals.

The starter diets (up to $15 \mathrm{~kg} \mathrm{BW}$ ) for T1, T2 and T3 groups contained 8.0, 8.0 and $6.2 \mathrm{~g} / \mathrm{kg}$ of total $\mathrm{P}$ (tP) respectively, which was in accordance to the recommendations of Serbian Rule Book (2010) and NRC (1998) standards for weaner pigs. The diet for group T4 contained $4.4 \mathrm{~g} / \mathrm{kg}$ of total P (tP) which was below both mentioned standards. The diets phytic $\mathrm{P}(\mathrm{pP})$ content was identical in all treatment groups $(2.3 \mathrm{~g} / \mathrm{kg})$. Composition and chemical analysis of starter diets (up to $15 \mathrm{~kg} \mathrm{BW}$ ) are presented in Table 1.

Table 1. Composition and chemical analysis of the starter diets (up to $15 \mathrm{~kg} \mathrm{BW}$ )

\begin{tabular}{|c|c|c|c|c|}
\hline Item & $\mathrm{T} 1$ & $\mathrm{~T}^{\mathrm{a}}$ & $\mathrm{T}^{\mathrm{a}}$ & $\mathrm{T} 4^{\mathrm{a}}$ \\
\hline \multicolumn{5}{|l|}{ Composition (\% as-fed basis) } \\
\hline Corn & 65.5 & 65.5 & 65.7 & 65.8 \\
\hline Soybean meal & 21.0 & 21.0 & 21.0 & 21.0 \\
\hline Sunflower meal & 4.0 & 4.0 & 4.0 & 4.0 \\
\hline Livestock yeast & 4.0 & 4.0 & 4.0 & 4.0 \\
\hline Animal fat & 2.0 & 2.0 & 2.0 & 2.0 \\
\hline Limestone flour & 1.1 & 1.1 & 1.5 & 1.9 \\
\hline Dicalcium phosphate & 1.0 & 1.0 & 0.5 & - \\
\hline Salt & 0.3 & 0.3 & 0.3 & 0.3 \\
\hline Chromium (III) oxide $\left(\mathrm{Cr}_{2} \mathrm{O}_{3}\right)^{\mathrm{b}}$ & 0.1 & 0.1 & 0.1 & 0.1 \\
\hline Minerals and vitaminsc & 1.0 & 1.0 & 1.0 & 1.0 \\
\hline \multicolumn{5}{|l|}{ Analyzed compositiond (\% DM) } \\
\hline Crude protein & 20.00 & 20.00 & 20.02 & 20.05 \\
\hline Fat & 4.87 & 4.87 & 4.89 & 4.89 \\
\hline Cellulose & 3.64 & 3.64 & 3.65 & 3.65 \\
\hline $\mathrm{Ca}$ & 1.06 & 1.06 & 1.04 & 1.03 \\
\hline tP (total P) & 0.80 & 0.80 & 0.62 & 0.44 \\
\hline aP (available $\mathrm{P}$ ) & 0.36 & 0.36 & 0.24 & 0.11 \\
\hline \multicolumn{5}{|l|}{ Calculated compositione } \\
\hline Lysine & 1.08 & 1.08 & 1.08 & 1.08 \\
\hline Methionine and cysteine & 0.61 & 0.61 & 0.61 & 0.61 \\
\hline Tryptophan & 0.28 & 0.28 & 0.28 & 0.28 \\
\hline Gross energy (MJ/kg) & 14.15 & 14.15 & 14.19 & 14.23 \\
\hline pP (phytic P) & 0.23 & 0.23 & 0.23 & 0.23 \\
\hline
\end{tabular}

${ }^{a}$ Experimental diets were supplemented with phytase (1000 FTU/kg for T2, T3 and T4 diets). Phytase

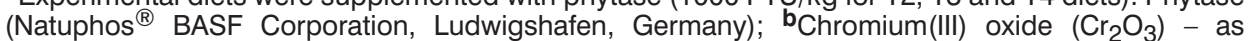


Acta Veterinaria (Beograd), Vol. 62, No. 5-6, 627-639, 2012.

Sefer $\mathrm{D}$ et al.: Effect of phytase supplementation

on growing pigs performance

digestibility indicator; ${ }^{C}$ Premix provided per $\mathrm{kg}$ of complete diet: $3 \mathrm{mg}$ retinol, $0.05 \mathrm{mg}$ cholecalciferol, $40 \mathrm{mg} \alpha$-tocopherol, $90 \mathrm{mg}$ copper as copper sulphate, $100 \mathrm{mg}$ iron as iron sulphate, $100 \mathrm{mg}$ zinc as zinc oxide, $0.3 \mathrm{mg}$ selenium as sodium selenite, $25 \mathrm{mg}$ manganese as manganous oxide and $0.2 \mathrm{mg}$ iodine as calcium iodate on a calcium sulphate/calcium carbonate carrier; ${ }^{d}$ Chemically determined (\% of Dry Matter - \%DM) ( $n=12)$; eINRA-AFZ (2004).

The grower diets (from 15 to $25 \mathrm{~kg} \mathrm{BW)} \mathrm{for} \mathrm{groups} \mathrm{T1} \mathrm{and} \mathrm{T2} \mathrm{contained}$ $6.1 \mathrm{~g} / \mathrm{kg}$ of total P (tP) which was in accordance to the recommendations of both Serbian Rule Book (2010) and NRC (1998) standards for weaner pigs. The grower diets of T3 and T4 groups contained 5.3 and $4.5 \mathrm{~g} / \mathrm{kg}$ of total P (tP), respectively which was below the mentioned recommendations. The diets phytic P (pP) content was identical in all treatment groups $(2.4 \mathrm{~g} / \mathrm{kg})$. Composition and chemical analysis of grower diets (from 15 to $25 \mathrm{~kg} \mathrm{BW}$ ) are presented in Table 2.

Table 2. Composition and chemical analysis of the grower diets (from 15 to $25 \mathrm{~kg} \mathrm{BW}$ )

\begin{tabular}{|c|c|c|c|c|}
\hline Item & T1 & $\mathrm{T} 2^{\mathrm{a}}$ & T3 ${ }^{a}$ & $\mathrm{~T} 4^{\mathrm{a}}$ \\
\hline \multicolumn{5}{|l|}{ Composition (\% as-fed basis) } \\
\hline Corn & 59.6 & 59.6 & 59.9 & 60.2 \\
\hline Soybean meal & 23.0 & 23.0 & 23.0 & 23.0 \\
\hline Sunflower meal & 6.0 & 6.0 & 6.0 & 6.0 \\
\hline Livestock yeast & 5.0 & 5.0 & 5.0 & 5.0 \\
\hline Animal fat & 2.0 & 2.0 & 2.0 & 2.0 \\
\hline Limestone flour & 1.0 & 1.0 & 1.7 & 2.4 \\
\hline Dicalcium phosphate & 2.0 & 2.0 & 1.0 & - \\
\hline Salt & 0.3 & 0.3 & 0.3 & 0.3 \\
\hline Chromium(III) oxide $\left(\mathrm{Cr}_{2} \mathrm{O}_{3}\right) \mathbf{b}$ & 0.1 & 0.1 & 0.1 & 0.1 \\
\hline Minerals and vitamins $\mathbf{c}$ & 1.0 & 1.0 & 1.0 & 1.0 \\
\hline \multicolumn{5}{|l|}{ Analyzed composition d (\% DM) } \\
\hline Crude protein & 18.26 & 18.26 & 18.27 & 18.28 \\
\hline Fat & 5.02 & 5.02 & 5.03 & 5.03 \\
\hline Cellulose & 3.34 & 3.34 & 3.35 & 3.35 \\
\hline $\mathrm{Ca}$ & 0.82 & 0.82 & 0.83 & 0.83 \\
\hline tP (total P) & 0.61 & 0.61 & 0.53 & 0.45 \\
\hline aP (available P) & 0.22 & 0.22 & 0.17 & 0.11 \\
\hline \multicolumn{5}{|l|}{ Calculated composition $\mathbf{e}$} \\
\hline Lysine & 0.96 & 0.96 & 0.96 & 0.96 \\
\hline Methionine and cysteine & 0.55 & 0.55 & 0.55 & 0.55 \\
\hline Tryptophan & 0.26 & 0.26 & 0.26 & 0.26 \\
\hline Gross energy (MJ/kg) & 14.28 & 14.28 & 14.29 & 14.31 \\
\hline pP (phytic P) & 0.24 & 0.24 & 0.24 & 0.24 \\
\hline
\end{tabular}




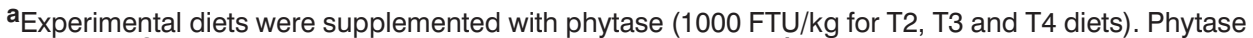
(Natuphos ${ }^{\circledR}$ BASF Corporation, Ludwigshafen, Germany); ${ }^{\mathbf{b}}$ Chromium(III) oxide $\left(\mathrm{Cr}_{2} \mathrm{O}_{3}\right)$ - as digestibility indicator; ' Premix provided per kg of complete diet: $3 \mathrm{mg}$ retinol, $0.05 \mathrm{mg}$ cholecalciferol, $40 \mathrm{mg} \alpha$-tocopherol, $90 \mathrm{mg}$ copper as copper sulphate, $100 \mathrm{mg}$ iron as iron sulphate, $100 \mathrm{mg}$ zinc as zinc oxide, $0.3 \mathrm{mg}$ selenium as sodium selenite, $25 \mathrm{mg}$ manganese as manganous oxide and $0.2 \mathrm{mg}$ iodine as calcium iodate on a calcium sulphate/calcium carbonate carrier; ${ }^{\mathrm{d}}$ Chemically determined (\% of Dry Matter - \%DM) ( $n=12)$; eINRA-AFZ (2004)

Laboratory analysis of samples. Diets were analyzed for dry matter, fat, cellulose, proteins and crude ash (AOAC, 1997). The dry matter were determined after drying for $24 \mathrm{~h}$ at $100^{\circ} \mathrm{C}$ and the crude ash content was determined after ignition of a weighed sample in a muffle furnace at $550^{\circ} \mathrm{C}$ for $6 \mathrm{~h}$. The ash was then digested in aqua regia $\left(\mathrm{HCl} / \mathrm{HNO}_{3}\right.$ mixture). This solution was used for $\mathrm{P}$ and $\mathrm{Ca}$ determination. The Ca concentration was determined using an atomic absorption spectrophotometer (Perkin-Elmer Analyst 700 MHS) using the method of Ramakrishna et al. (1968). The concentration of $P$ was determined spectrophotometrically using the method of Cavell (1955). The dietary gross energy $(\mathrm{MJ} / \mathrm{kg})$, concentrations of lysine, tryptophan, methionine and cysteine, as well as pP (phytic P) were calculated according to INRA-AFZ (2004).

Calculations and statistics. Statistical analysis of intergroup differences of means was performed by ANOVA, Tukey multiple comparison test was used. Software package Prism Pad v. 5.0 (Graph Pad Software Inc., San Diego, CA, USA) was used for statistical evaluation. Data were expressed as means \pm standard deviation. Differences with $\mathrm{p}<0.05$ were considered statistically significant.

\section{RESULTS}

During the study piglets from all experimental groups were of good health, no deaths were recorded, nor loss of appetite. At the beginning of the study body mass of piglets was not significantly different between experimental groups $(p>$ 0.05). Differences were not significant nor after the first and second phase of the study (day $20^{\text {th }}$ and $40^{\text {th }}$ ), which is shown in Table 3.

Table 3. Piglet body mass $(\mathrm{kg})$

\begin{tabular}{|c|c|c|c|c|}
\hline Day of the study & T1 & T2 & T3 & T4 \\
\hline \hline $1^{\text {st }}$ & $8.71 \pm 0.90$ & $8.71 \pm 1.00$ & $8.73 \pm 0.88$ & $8.73 \pm 1.17$ \\
\hline Index & 100.00 & 100.00 & 100.23 & 100.23 \\
\hline $20^{\text {th }}$ & $15.35 \pm 1.81$ & $15.45 \pm 1.94$ & $15.13 \pm 2.39$ & $14.51 \pm 2.59$ \\
\hline Index & 100.00 & 100.65 & 98.57 & 94.53 \\
\hline $40^{\text {th }}$ & $23.67 \pm 3.56$ & $25.23 \pm 2.51$ & $25.45 \pm 3.36$ & $22.98 \pm 2.56$ \\
\hline Index & 100.00 & 106.59 & 107.52 & 97.08 \\
\hline
\end{tabular}


Acta Veterinaria (Beograd), Vol. 62, No. 5-6, 627-639, 2012.

Average daily body weight gain (BWG), in the period from $1^{\text {st }}$ to $20^{\text {th }}$ day of the study, was significantly lower in the T4 group of piglets (fed diet without supplemented inorganic phosphorous plus added phytase enzyme) compared to the other groups of piglets $(p<0.05)$. In the period from the $21^{\text {st }}$ to $40^{\text {th }}$ day of the study, T2 and T3 group of piglets achieved better daily body weight gain compared to T1 and T4 groups of piglets $(p<0.05)$. The average daily body weight gain for the whole study period was lowest in group T4 and highest in group T3. The measured daily body weight gain of the piglets in T4 was significantly lower compared to T3 $(p<0.01)$ and T2 group $(p<0.05)$, the results are shown in Table 4.

Table 4. Average daily body weight gain (BWG) $(\mathrm{kg})$

\begin{tabular}{|c|c|c|c|c|}
\hline Day of the study & $\mathrm{T} 1$ & $\mathrm{~T} 2$ & $\mathrm{~T} 3$ & $\mathrm{~T} 4$ \\
\hline \hline $1^{\text {st }}$ to $20^{\text {th }}$ & $0.348 \pm 0.051^{\mathrm{a}}$ & $0.363 \pm 0.052^{\mathrm{b}}$ & $0.367 \pm 0.047^{\mathrm{c}}$ & $0.272 \pm 0.038^{\mathrm{a}, \mathrm{b}, \mathrm{c}}$ \\
\hline Index & 100.00 & 104.31 & 105.46 & 78.16 \\
\hline $21^{\text {st }}$ to $40^{\text {th }}$ & $0.380 \pm 0.049^{\mathrm{a}, \mathrm{b}}$ & $0.452 \pm 0.025^{\mathrm{a}, \mathrm{c}}$ & $0.453 \pm 0.049^{\mathrm{b}, \mathrm{d}}$ & $0.384 \pm 0.027^{\mathrm{c}, \mathrm{d}}$ \\
\hline Index & 100.00 & 118.95 & 119.21 & 101.05 \\
\hline $1^{\text {st }}$ to $40^{\text {th }}$ & $0.364 \pm 0.033$ & $0.406 \pm 0.053^{\mathrm{a}}$ & $0.408 \pm 0.029^{\mathrm{A}}$ & $0.345 \pm 0.021^{\mathrm{A}, \mathrm{a}}$ \\
\hline Index & 100.00 & 112.78 & 113.33 & 95.83 \\
\hline
\end{tabular}

Same letters differ at $a, b, c, d p<0.05, A p<0.01$.

The amount of consumed feed per day measured in this study is shown in Table 5. No significant differences in the amount of feed consumed between control and all experimental groups of piglets during all study period $\left(1^{\text {st }}\right.$ till $40^{\text {th }}$ day of the study) were observed $(p>0.05)$. However, it was observed that the control group of piglets (T1) consumed less feed (per day) compared to T2, T3 and T4 group of piglets (for $7.84,8.73$, and $5.77 \%$ respectfully).

Table 5. Feed consumption per day (kg)

\begin{tabular}{|c|c|c|c|c|}
\hline Day of the study & T1 & T2 & T3 & T4 \\
\hline \hline $1^{\text {st }}$ to $20^{\text {th }}$ & 0.520 & 0.528 & 0.512 & 0.538 \\
\hline Index & 100.00 & 100.57 & 97.52 & 102.48 \\
\hline $21^{\text {st }}$ to $40^{\text {th }}$ & 0.827 & 0.930 & 0.958 & 0.892 \\
\hline Index & 100.00 & 112.45 & 115.84 & 107.86 \\
\hline $1^{\text {st }}$ to $40^{\text {th }}$ & 0.676 & 0.729 & 0.735 & 0.715 \\
\hline Index & 100.00 & 107.84 & 108.73 & 105.77 \\
\hline
\end{tabular}

Feed efficiency (feed conversion ratio FCR) is shown in Table 6. In the period from $1^{\text {st }}$ to $20^{\text {th }}$ day the lowest feed conversion ratio was measured in group T2 and highest in group T4. The situation in the second phase of the study $\left(21^{\text {st }}\right.$ to $40^{\text {th }}$ day) was similar, but the difference was more pronounced. Taking into 
account the entire study period ( $1^{\text {st }}$ to $40^{\text {th }}$ day) FCR in T2 and T3 was by $3.23 \%$ lower and in $\mathrm{T} 4$ by $11.29 \%$ higher compared to the control group of piglets (T1).

Table 6. Feed efficiency $(\mathrm{kg})$

\begin{tabular}{|c|r|r|r|r|}
\hline Day of the study & \multicolumn{1}{|c|}{ T1 } & T2 & \multicolumn{1}{c|}{ T3 } & T4 \\
\hline \hline $1^{\text {st }}$ to $20^{\text {th }}$ & 1.58 & 1.57 & 1.60 & 1.86 \\
\hline Index & 100.00 & 99.30 & 101.20 & 117.70 \\
\hline $21^{\text {st }}$ to $40^{\text {th }}$ & 2.18 & 2.06 & 2.11 & 2.32 \\
\hline Index & 100.00 & 94.50 & 96.79 & 106.42 \\
\hline $1^{\text {st }}$ to $40^{\text {th }}$ & 1.86 & 1.80 & 1.80 & 2.07 \\
\hline Index & 100.00 & 96.77 & 96.77 & 111.29 \\
\hline
\end{tabular}

\section{DISCUSSION}

The phosphorous deficiency in nutrition due to its role in the processes of energy transfer disturbs biosynthetic reactions and leads to depressed growth of the young, as well as lower production results of mature animals (Šefer, 2002). In our study the control group of piglets (T1) achieved standard body mass for its breed and age while addition of phytase in the meal increased body mass by $6.59 \%$ and $7.52 \%$ in T2 and T3, respectively. On the contrary in group T4 (no inorganic phosphorous supplemented plus phytase) the decrease in body mass by $2.92 \%$ compared to the control group (T1) of piglets was not statistically significant $(p>0.05)$. Judging by the results in group T2 and T3, phytase addition completely prevented negative effects of lower total available phosphorous. The finding that phytase had a weak effect on group T4 is in accordance to the findings of Qian et al. (1996). The mentioned authors concluded that phytase is most efficient in the diets with low available phosphorous and in diets were Ca to $\mathrm{P}$ ratio is $2: 1$ and that the positive effects of phytase supplementation decrease together with the decrease of phosphorous content in the diets. A more controversial area is whether or not phytase enhances growth performance of pigs offered $P$ adequate diets and, if so, the genesis of these responses should be elucidated. Beers and Jongbloed (1992) reported the first example of phytase enhancing performance was in pigs offered P-adequate diets. They reported that 1450 FTU $\mathrm{kg}^{-1}$ phytase increased growth rate by $12.8 \%$, feed intake by $8.5 \%$ and feed efficiency by $4.4 \%$ in diets for weaner pigs containing to $2.9 \mathrm{~g} \mathrm{~kg}^{-1}$ nonphytate $P$. As these responses could not be attributed to enhanced $P$ digestibility, one explanation was that phytase may have increased protein/amino acids digestibility, as it may be relevant that the diets contained relatively low protein $\left(185 \mathrm{~g} \mathrm{~kg}^{-1}\right)$ levels.

Phytate is a polyanionic molecule with the potential to chelate positively charged nutrients, which is almost certainly fundamental to the anti-nutritive properties of phytate. These anti-nutritive properties require further investigation, 
but phytate probably compromises the utilization of protein/amino acids, energy, calcium and trace minerals (Selle and Ravidran, 2007).

Average daily body weight gain is considered a reliable indicator of feed quality, especially in the investigation of phosphorous bioavailability in feedstuffs (Šefer, 2002).

Average daily body weight gain (BWG), in the period from the $1^{\text {st }}$ to the $20^{\text {th }}$ day of the study, was significantly lower in the T4 group of piglets (fed the diet without supplemented inorganic phosphorous plus added phytase enzyme) compared to the other groups of piglets $(p<0.05)$. Phytase supplementation in groups T2 and T3 prevented decreased body weight gain when compared to the control, however this was not the case for group T4, where available phosphorous was at only $30 \%$ of the level of available phosphorous in the control group (T1). In the period from the $21^{\text {st }}$ to the $40^{\text {th }}$ day of the study, T2 and T3 groups of piglets had achieved better daily body weight gain compared to T1 and T4 groups of piglets $(p<0.05)$. The average daily body weight gain for the whole study period was lowest in T4 and highest in T3 group of piglets. The fact that the measured daily body weight gain of the piglets in T4 was significantly lower compared to T3 $(p<0.01)$ and T2 group $(p<0.05)$ is worth mentioning.

Previous research has demonstrated that phytase supplementation in weaner pig diets has the ability to improve weaner pig feed efficiency (Brana et al., 2006; Woyengo et al., 2008). Exogenous phytase has been shown to increase blood glucose concentrations in pigs (Johnston et al., 2004; Kies et al., 2005) and it is likely that phytate impedes glucose uptake in humans (Selle and Ravidran, 2007). Predictably, phytase feed enzymes have the capacity to enhance growth performance of pigs offered P-deficient diets (Selle and Ravidran, 2007). Similar 'extra-phosphoric' responses in growth performance of weaner pigs offered wheat-based diets were reported by Campbell et al. (1995). In this study, 500 FTU $\mathrm{kg}^{-1}$ phytase improved weight gain and feed efficiency of weaner pigs offered diets containing either 3.5 or $4.5 \mathrm{~g} \mathrm{~kg}^{-1}$ available $\mathrm{P}$ with an average of 14.4 and $9.2 \%$, respectively. In contrast, however, Barnett et al. (1993) did not observe enhanced growth performance in weaner pigs offered conventional, wheat-based diets following $1000 \mathrm{FTU} \mathrm{kg}^{-1}$ phytase addition. However, retrospective estimates of dietary phytate concentrations indicated that there were substantial differences in substrate levels between the two studies (Selle et al., 1997). In the Barnett et al. (1993) study the diets contained approximately $2.0 \mathrm{~g} \mathrm{~kg}^{-1}$ phytate-P; whereas, in the Campbell et al. (1995) study, the diets contained an estimated $3.9 \mathrm{~g} \mathrm{~kg}^{-1}$ phytate-P. These contrasting results suggest that dietary substrate levels are an important determinant of the magnitude of phytase responses.

The amount of consumed feed per day measured in our study was not significantly different $(p>0.05)$. However, it was observed that the control group of piglets (T1) consumed less feed daily, compared to groups T2, T3 and T4. This finding is not surprising since the fact that dietary phosphorus deficiency has an immediate depressing effect on appetite, growth rate, and feed efficiency of swine (NRC, 1998; Crenshaw, 2001). Our finding is similar to the findings of Harper et al. (1997) who have found that supplemental phytase can prevent decreased 
appetite in low phosphorous diets and even increase consumption of diets low in available phosphorous.

Feed efficiency (feed conversion ratio) as an interaction between body weight gain and amount of feed consumed was different between groups. Feed efficiency for T2 and T3 groups was by 3.23\% better and for T4 by $11.29 \%$ lower compared to the control group of piglets (T1) throughout the study period. The attitude towards phytase effects on feed efficiency is somewhat controversial. Cromwell et al. (1993) found that phytase supplementation of diets low in phosphorous affects body weight gain and feed consumption without effects on feed efficiency. On the contrary Yi et al. (1996) and Harper et al. (1997) reported that besides other positive effects phytase supplementation increased feed efficiency.

In a series of three feeding studies reported by Selle et al. (2003), microbial phytase ( 550 to $750 \mathrm{FTU} \mathrm{kg}^{-1}$ ) generated overall improvements in weight gain by an average of $9.4 \%$ (401 versus $367 \mathrm{~g} \mathrm{day}^{-1}$ ) and feed efficiency by $6.1 \%$ (1.23 versus 1.31) in weaner pigs offered phosphorus-adequate, lysine-deficient, wheat based diets. Also, there was a positive correlation between percentage improvements in feed efficiency in response to phytase and dietary phytate contents $(r=0.923$; Pb0.005). In one experiment, diets containing 1.2, 2.2 and $3.2 \mathrm{~g} \mathrm{~kg}^{-1}$ phytate-P were offered to pigs without and with $625 \mathrm{FTU} \mathrm{kg}^{-1}$ phytase. While responses to phytase appeared to be more pronounced in the high phytate diets (weight gain: 12.1\%; feed efficiency:10.8\%) than in the low phytate diets (weight gain:-1.30\%; feed efficiency: 0.0\%), treatment interactions were not statistically significant.

The validity of responses to phytase in $\mathrm{P}$ adequate diets have been challenged on the basis that enzymic 'side-activities' in phytase preparations may be generating independent, positive effects (Farrell and Martin, 1998; Driver et al., 2006). While side-activities have been identified in phytase feed enzymes (Zyla et al., 2000) it is questionable if they could exert any tangible, independent effects at recommended inclusion rates although it is possible that they may facilitate phytase activity. It is understood that certain phytase feed enzymes contain acid phosphatase side-activity, which would augment phytate hydrolysis by phytase (Zyla, 1993).

Finally, by observing all production results obtained in this study we can confirm that the best production results were achieved in the group of pigs fed a diet with the recommended amount of phosphorous plus supplemental phytase. Interestingly, feeding diets with a lower amount of mineral source of phosphorous supplemented with phytase resulted in nearly as good production results as with adequate phosphorous diet thus confirming the fact that phytase has successfully freed the necessary amount of phosphorous from is phytic form.

In summary, based on the results of our study we can conclude that lower production results achieved by the use of diets low in phosphorous can be avoided to a certain level by the use of microbial phytase. The use of phytase in pig diet significantly improved phosphorous availability, as well as of other mineral matters from the phytate complex and therefore reduces soil contamination by undigested nutrient matters. Finally, we can conclude that up to $30 \%$ of total or up 
Acta Veterinaria (Beograd), Vol. 62, No. 5-6, 627-639, 2012.

to $50 \%$ of available phosphorous can be efficiently substituted by the inclusion of $1000 \mathrm{FTU} / \mathrm{kg}$ of phytase.

ACKNOWLEDGEMENT:

This work was supported by grant No III46002 Serbian Ministry of Education, Science and Technology.

Address for correspondence:

Dr Dragan Šefer

University of Belgrade

Faculty of Veterinary medicine

Bulevar oslobođenja 18

11000 Belgrade, Serbia

E-mail: dsefer@vet.bg.ac.rs

\section{REFERENCES}

1. AOAC, 1997, Official Methods of Analysis, Association of Official Analytical Chemists, $16^{\text {th }}$ edition, Washington, DC, USA.

2. Barnett BJ, Clarke WA, Batterham ES, 1993, Has phytase a proteolytic effect in diets for weaner pigs? Manipulating Pig Production IV, Australasian Pig Science Association, Werribee, Vic, 227.

3. Beers S, Jongbloed AW, 1992, Effect of supplementary Aspergillus niger phytase in diets for piglets on their performance and apparent digestibility of P, Anim Prod, 55, 425-30.

4. Brana DV, Ellis M, Castaneda EO, Sands JS, Baker DH, 2006, Effect of a novel phytase on growth performance, bone ash, and mineral digestibility in nursery and grower-finisher pigs, J Anim Sci, 84, 1839-49.

5. Campbell RG, Harrison DT, Butler KJ, Selle PH, 1995, Effect of dietary available phosphorus and phytase (Natuphos) on the performance of pigs from 19-40 days post-weaning, Manipulating Pig Production V Australasian Pig Science Association, Werribee, Vic, 193.

6. Cavell AJ, 1955, The spectrophotometric determination of phosphorus in plant material, J Sci Food Agric, 6, 479-80.

7. Cordell D, Drangert JO, White $S, 2009$, The story of phosphorus: global food security and food for thought, Glob Environ Change, 19, 292-305.

8. Cowieson AJ, Acamovic T, Bedford MR, 2004, The effects of phytase and phytic acid on the loss of endogenous amino acids and minerals from broiler chickens, Br Poult Sci, 45, 101-8.

9. Crenshaw TD, 2001, Calcium, Phosphorus, Vitamin D, and Vitamin K in swine nutrition, In: Swine Nutrition, Second Edition, Edited by AJ Lewis and LL Southern, 187-212.

10. Cromwell GL, Stahky TS, Coffey RD, Moneque HJ, Randolph JH, 1993, Efficacy of phytase in improving the bioavailability of phosphorous in soybean meal and corn-soybean meal diets for pigs, J Anim Sci, 71, 1831-40.

11. Driver JP, Antencio A, Edwards HM, Pesti GM, 2006, Improvements in nitrogen-corrected apparent metabolizable energy of peanut meal in response to phytase supplementation, Poult Sci, 85, 96-9.

12. Engelen AJ, van der Heeft FC, Randsdorp PHG, Smit ELC, 1994, Simple and rapid determination of phytase activity, $J$ AOAC Int, 77, 760-4.

13. Farrell DJ, Martin E, 1998, Strategies to improve the nutritive value of rice bran in poultry diets, III. The addition of inorganic phosphorus and a phytase to duck diets, Br Poult Sci, 39, 601-11.

14. Garrett JB, Kretz KA, O'Donoghue E, Kerovuo J, Kim W, Barton NR et al., 2004, Enhancing the thermal tolerance and gastric performance of a microbial phytase for use as a phosphatemobilizing monogastric-feed supplement, Appl Environ Microbiol, 70, 3041-6.

15. Harper AF, Kornegay ET, Schell TC, 1997, Phytase supplementation of low phosphorous growingfinishing pig diets improves performance, phosphorous digestibility and bone mineralization nad reduces phosphorous excretion, $J$ Anim Sci, 75, 3174-86

16. Hartig T, 1855, Uber das Klebermehl, Botanische Z, 13, 881-5. 
17. INRA-AFZ, 2004, Tables of composition and nutritional value of feed materials; pigs, poultry, cattle, sheep, goats, rabbits, horses, fish, In: Sauvant D, Perez JM, Tran G (Eds.), INRA-AFZ. Wageningen Academic Publishers, The Netherlands, 13-300.

18. Johnston SL, Williams SB, Southern LL, Bidner TD, Bunting LD, Matthews JO et al., 2004, Effect of phytase addition and dietary calcium and phosphorus levels on plasma metabolites and ileal and total tract nutrient digestibility in pigs, J Anim Sci, 82, 705-14.

19. Kies AK, Gerrits WJJ, Schrama JW, Heetkamp MJW, van der Linden KL, Zandstra $T$ et al., 2005, Mineral absorption and excretion as affected by microbial phytase, and their effect on energy metabolism in young piglets, $J$ Nutr, $135,1131-8$.

20. Lott JNA, Ockenden I, Raboy V, Batten GD, 2000, Phytic acid and phosphorus in crop seeds and fruit: a global estimate, Seed Sci Res, 10, 11-33.

21. Lowe JT, Steenbock H, Keiger CH, 1939, Cereals and rickets, IX. The availability pf phytin-P to the chick, Poult Sci, 18, 40-4.

22. Mullaney EJ, Daly CB, Ullah AHJ, 2000, Advances in phytase research, Adv Appl Microbiol, 47, 15799.

23. NRC, 1998, National Research Council, Nutrient Requirements of Swine, $10^{\text {th }}$ edition. National Academy Press, Washington DC, 111-41.

24. Qian H, Kornegay ET, Conner DE, 1996, adverse effects of wide calcium:phosphorous ratios on supplemental phytase efficacy for weaning pigs fed two dietary phosophorous levels, J Anim Feed Sci, 74, 1287-97.

25. Ramakrishna TV, West W, Robinson JW, 1968, The determination of calcium and magnesium in acetylene flames, Anal Chim Acta, 40, 347-50.

26. Ravindran V, Morel PCH, Partridge GG, Hruby M, Sands JS, 2006, Influence of an E. coli-derived phytase on nutrient utilization in broiler starter fed diets containing varying concentrations of phytic acid, Poult Sci, 85, 82-9.

27. Šefer D, 2002, Efekat korišćenja fitaze u ishrani prasadi na proizvodne rezultate, iskoristivost fosfora i stepen mineralizacije koštanog tkiva, Doktorska disertacija, Fakultet veterinarske medicine Univerziteta u Beogradu (in Serbian).

28. Šefer D, Sinovec Z, 2008, Opšta ishrana, Fakultet veterinarske medicine Univerziteta u Beogradu, 91-2 (in Serbian).

29. Selle PH, Ravindran V, 2008, Phytate-degrading enzymes in pig nutrition, Livestock Sci, 113, 99122.

30. Selle PH, Ravindran V, Ravindran G, Bryden WL, 2007, Effects of dietary lysine and microbial phytase on growth performance and nutrient utilisation of broiler chickens, Asian-Australas $J$ Anim Sci, 20, 7, 1100-7.

31. Selle PH, Cadogan DJ, Bryden WL, 2003, Effects of phytase supplementation of phosphorusadequate, lysine-de?cient, wheat-based diets on growth performance of weaner pigs, Aust $J$ Agric Res, 54, 323-30.

32. Serbian rule book, 2010, Pravilnik o kvalitetu hrane za životinje, Službeni Glasnik 4/2010 (in Serbian).

33. Suzuki U, Yoshimura K, Takaishi M, 1907, Uber ein Enzym "Phytase" das Anhydro-oxymethylendiphosphosaure spaltet, Coll Agric Bull Tokyo Imp Univ, 7, 503-5.

34. Swick RA, Ivey FJ, 1992, Phytase: the value of improving phosphorus retention, Feed Manage, 43, 8-17.

35. Vats P, Bhattacharyya MS, Banerjee UC, 2005, Use of phytases (myoinositolhexakis-phosphate phosphohydrolases) for combating environmental pollution: a biological approach, Crit Rev Environ Sci Technol, 35, 469-86.

36. Wodzinski RJ, Ullah AHJ, 1996, Phytase, Adv Appl Microbiol, 42, 263-303.

37. Woyengo TA, Sands JS, Guenter W, Nyachoti CM, 2008, Nutrient digestibility and performance responses of growing pigs fed phytase and xylanase supplemented wheat based diets, J Anim Sci, 86, 848-57.

38. Wyss M, Pasamontes L, Remy R, Kohler J, Kusznir E, Gradient M et al., 1998, Comparison of the thermostability properties of three acid phosphatases from molds: Aspergillus fumigatus 
phytase, A. niger phytase, and A. niger pH 2.5 acid phosphatase, Appl Environ Microbiol, 64, 4446-51.

39. Yi Z, Kornegay ET, Ravindan V, Lindemann MD, Wilson HJ, 1996, Effectivness of Natuphos phytase in improving the bioavailabilities of phosphorous and other nutrients in soybean meal-based semipurified diets for young pigs, J Anim Sci, 74, 1601-11.

40. Zyla K, 1993, The role of acid phosphatase activity during enzymic dephosphorylation of phytates by Aspergillus niger phytase, World J Microbiol Biotechnol, 9, 117-9.

41. Zyla K, Wikiera A, Koreleski J, Swiatkiewicz S, Piironen J, Ledoux DR, 2000, Comparison of the efficacies of a novel Aspergillus niger phytase with separate and combined effectiveness of phytase, acid phosphatase and pectinase in dephosphorylation of wheat-based diets fed to growing broilers, Poult Sci, 79, 1434-43.

\title{
UTICAJ DODAVANJA FITAZE U HRANU NA ZDRAVSTVENI STATUS I PROIZVODNE REZULTATE SVINJA U TOVU
}

\author{
ŠEFER D, PETRUJKIĆ B, MARKOVIĆ RADMILA, GRDOVIĆ SVETLANA, NESTOROVIĆ B, \\ BOGOSAVLJEVIĆ V, KOKOŠKOV N i MILIĆ D
}

\section{SADRŽAJ}

Zbog izraženih antinutritivnih svojstava fitata i negativnog uticaja na iskorišćavanje fosfora, njihova koncentracija u hrani je od velikog značaja. Poznato je da visoka koncentracija fitata u hrani povećava endogene gubitke amino kiselina i minerala kod svinja. Delimična dostupnost fosfora iz fitata kod monogastičnih životinja još više dobija na značaju usled činjenice da svetske rezerve mineralnog fosfora iz stena nisu obnovljive i da to može dovesti do krize u snabdevanju fosforom u budućnosti. Dodavanje fitaze postaje sve popularnije kao metod za povećanje dostupnosti fosfora u biljnim sirovinama koje sadrže visoku koncentraciju fosfora. Četrdeset osam prasadi (Švedski Landras nerast $\times$ Danski Landras krmača) zalučenih u starosti od 35 dana prosečne telesne mase $8,72 \pm 0,28 \mathrm{~kg}$ je uključeno u 40-to dnevni ogled ispitivanja proizvodnih rezultata. Ogled je dizajniran sa ciljem da se ispita uticaj dodatka tri koncentracije fitaze poreklom od Aspergillus niger i to: (T1) bazalni obrok; (T2) bazalni obrok+1000 FTU/kg; (T3) obrok sa smanjenom koncentracijom dikalcijum fosfata + 1000 FTU/kg; and (T4) obrok bez dodatog dikalcijum fosfata $+1000 \mathrm{FTU} / \mathrm{kg}$.

Kontrolna grupa prasadi (T1) je postigla uobičajenu telesnu masu, dok je dodatak fitaze u obrok povećavao telesnu masu za 6,59\% u T2 i 7,52\% u T3. Dodavanje fitaze je preveniralo smanjenje prirasta kod smeša gde je koncentracija fosfora bila niža za $50 \%$ od potreba. Količina konzumirane hrane se nije značajnije razlikovala među oglednim grupama. Konverzija hrane u grupama T2 i T3 je bila bolja za 3,23\%, dok je u grupi T4 bila za 11,29\% lošija u poređenju sa kontrolnom grupom (T1).

Lošiji proizvodni rezultati pri korišćenju obroka sa niskim sadržajem fosfora se mogu izbeći upotrebom fitaze mikrobijalnog porekla. Korišćenje fiteze u hrani za svinje u tovu značajno poboljšava iskoristljivost fosfora i drugih mineralnih materija poreklom iz fitatnog kompleksa. 
